\title{
Money, Coins, and Archaeology
}

\author{
Nanouschka Myrberg Burström
}

\section{Money, Coins, and Archaeology: Trends in Scholarship}

The title of this chapter could refer to several different things: for example, the use of economic theory in archaeological research or the different grounds and sources for financing archaeology in different times and political settings, both interesting and valid topics for study. However, following the intention of the series Decoding Medieval Sources - to evaluate and exemplify how sources can be understood and put to use for medieval studies - the chapter will focus on the following three themes: conceptions of "money" and "coins" within archaeology, coins as archaeological material, and coins as part of archaeological research history. The focus will be on the medieval period but outlooks will be made to other times and areas where there are illustrative examples and to general issues of theory and method.

The connection between archaeology and coins, money and numismatics, has been repeatedly debated over recent decades. It was the focus of several publications, some of which should be mentioned at the start of this chapter in order to introduce the field. Importantly, Lloyd R. Laing's Coins and Archaeology (1969) addressed both "the archaeologist ... who wishes to learn more about the nature of numismatics and its application in archaeology" and "the numismatist who is unfamiliar with the work of the archaeologist, and who understands only imperfectly how he can help his colleagues in this field", ${ }^{1}$ clearly with the ambition to create a better understanding not only for the numismatic material itself but also between the two disciplines or groups of expertise. In 1973, John Casey and Richard Reece brought together a group of scholars to discuss the relationship among numismatics, coins, and archaeology, resulting in the volume Coins and the Archaeologist, ${ }^{2}$ which they later revised for a second edition. ${ }^{3}$ A similar initiative was undertaken in the 1980 s and materialized as the proceedings volume Coins and Archaeology. ${ }^{4}$ A thematic journal issue

1 Laing, Coins and Archaeology, Introduction.

2 Casey and Reece, Coins and the Archaeologist (1974).

3 Casey and Reece, Coins and the Archaeologist (1988).

4 Clarke and Schia, Coins and Archaeology. 
of Archäologie der Schweiz ${ }^{5}$ and one of META ${ }^{6}$ brought up similar questions, which were also in focus for the 2007 colloquium Coins in Context. ${ }^{7}$ A 1975 issue of World Archaeology ${ }^{8}$ centred on the theme Currency rather than on coins or money, but includes several aspects of what is discussed in the abovementioned volumes. Most recent and with a slightly different direction, but equally important, is the conference proceedings volume The Archaeology of Money, ${ }^{9}$ and the edited collection Divina Monet ${ }^{10}$ puts many of the ideas to work for a discussion of materiality and ritual pertaining to coins. It is perhaps telling that most of these efforts came about as conferences, aiming to discuss and investigate ways forward. The publications include many different cases demonstrating a variety of aspects, practices, and debates; curiosity and eagerness to develop the results clearly stand out. Efforts, albeit as single papers, to sum up and develop the coin-archaeology discourse were made in the 2o10s by Fleur Kemmers and Nanouschka Myrbergi1 and Colin Haselgrove and Stefan Krmnicek, ${ }^{12}$ and 2011 saw the birth of an entirely new journal dedicated to coins and archaeology, the Journal of Archceological Numismatics (published by the European Centre for Numismatic Studies, Brussels).

It is an impossible task to summarize all of the publications that have helped us to understand how to work with archaeological theory and method in relation to coins, since they are many and contributed in very different ways. A few examples will illustrate the diversity. In the 196os, Philip Grierson made two presidential addresses to the (British) Royal Numismatic Society ${ }^{13}$ which, in a comprehensive way, dealt with different types of coin finds and how and for what they may be used in historical research. Although archaeology is hardly mentioned explicitly, it is clear that his argument takes the contribution from archaeology for granted and it emphasizes that coins cannot really be studied apart from their historical and archaeological contexts. ${ }^{14}$ Two Swiss publications centre in a concrete and instructive way around coin finds from churches and graves, respectively. ${ }^{15}$ The work on coin finds in churches is continued

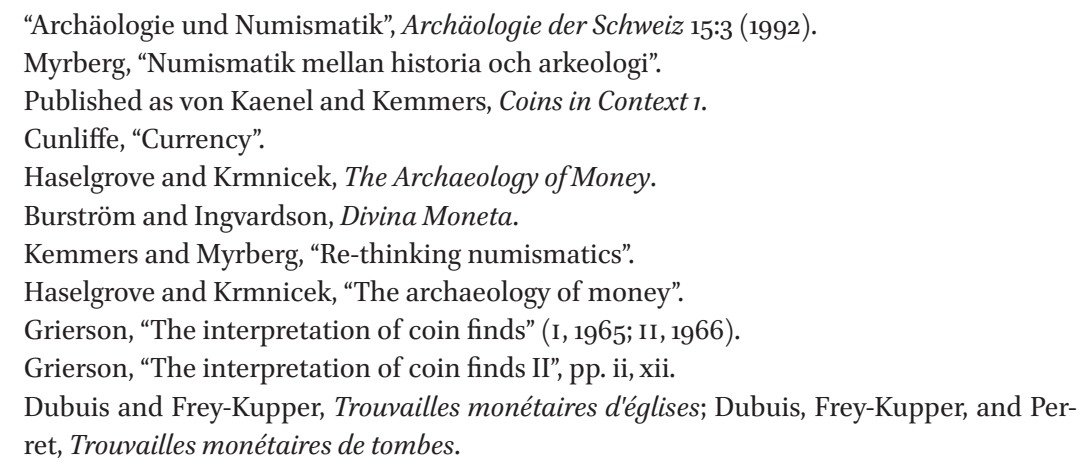


and developed in the Scandinavian project Religion and Money in the Middle Ages, ${ }^{16}$ which provides several in-depth studies where archaeological theory and method are put to use to further the research on this specific category of finds. John Creighton's book about British Iron Age coinage provides a stimulating model for how coins may be given complex interpretations by the use of historical, archaeological, and art historical sources, theory, and methods in combination. ${ }^{17}$

These are just a few examples of central works and of the diversity of inspiring and instructive works to turn to, which the reader may use as a starting point to get a quick introduction to the field. The aim of this chapter is to provide some further reflections on the nature of coins and money from an archaeological perspective, to point out how integrated coins are with the growth of archaeological theory and method, and to illustrate with a few examples how archaeology may further the study of coins - and vice versa.

\section{"Money" and "Coins" in Archaeological Thinking and Practice}

In the archaeological discipline, the difference between "money" and "coins" goes much further and deeper than to indicate different types of currencies or means of exchange. Naturally, such distinctions are made when deemed appropriate. But there is a more profound ambivalence in relation to "money" and "coins" which, I suggest, derives from within the discipline itself. Archaeology is an interdisciplinary field in its character, and even leaving its naturalscientific auxiliary branches out of the discussion, fundamentally it oscillates between history, with which it shares humanistic theory and method as well as diachronic scope, and anthropology, that shares with archaeology a focus on humans and their environment. Where on the scale between history and anthropology the archaeological scholar is situated depends largely on individual research objectives and, importantly, on the time period and empirical material treated.

When it comes to the issue of money, archaeologists have been much inspired by social and cultural anthropology, ${ }^{18}$ increasingly so since the 1980 os.

16 Gullbekk et al., The Use of Money in Religious and Devotional Contexts.

17 Creighton, Coins and Power in Late Iron Age Britain.

18 See, e.g., influential works by Appadurai, The Social Life of Things; Dalton, Studies in Economic Anthropology; Mauss, "Essai sur le don"; Strathern, The Gender of the Gift; Parry and Bloch, Money and the Morality of Exchange; Weiner, Inalienable Possessions; Hoskins, Biographical Objects; Graeber, Toward an Anthropological Theory of Value; and a summary 
This seems to be particularly true for pre- or proto-historical archaeologists, that is, those working on the time periods and places for which we have no historical (written) sources or only very particular ones (e.g., external sources such as traveller's accounts, or special-purpose and formulaic epigraphy). In pre- and proto-historical archaeology, ethnographic analogies and anthropological examples of the great diversity in cultural perceptions and organization have been valuable models for how to interpret the "mute" remains with more confidence. When discussing economy and money, pre- and proto-historical archaeologists are therefore rather likely to refer to emic ideas of gifts, cycles, exchange, barter, prestige, commodification, or "tournaments of value"19 than to commerce, trade, profit, remuneration, or monetization processes. The former concepts seem simply to hold a higher explanatory value for the investigated societies than do the latter, or are employed to avoid simplistic analogies between the past and the market mechanisms of the last few hundred years which may be inherent in an etic approach. The world of the social homo anthropologicus is presented as an alternative to the selfish and calculating world of homo economicus. ${ }^{20}$

With "money" may be included many types of valuables, such as African iron bars (kissipennies), medieval Russian silver bars (grivnas), beads (e.g., kauri shells or aggries of mineral or glass), neck rings and other ornaments, stones (like the famous ones of Yap), and many other things for which one can easily find analogies in the archaeological record. As an example, certain Viking-Age beads look very similar to aggry beads, and match tantalisingly in time with a passage where Ahmad Ibn Fadlan talks about the high value of certain beads esteemed and desired by eastern Vikings (Figure 10.1). ${ }^{21}$

Some of these monies have a known trading or currency function, while others are for special purposes only, like bride exchange. It has no doubt been fruitful for pre- and proto-historical archaeologists to work (more or less explicitly) with the understanding of these non-numismatic monies in order to find alternative perspectives for a past that cannot really be fitted into a present-day framework. Neither does, as pointed out by Walter $\mathrm{Ne}-$ ale, the use of money necessarily imply a "commercialized" society, nor do commercial activities necessarily mean that all fields of an economy are

of arguments within this field included in Papadopoulos and Urton, The Construction of Value in the Ancient World, pp. 12-21.

19 Appadurai, Social Life of Things, p. 21.

20 Papadopoulos and Urton, Construction of Value, p. 20.

21 Ibn Fadlan, Kitāb ilá malik al-ṣaqālibah; and Callmer, Trade Beads and Bead Trade in Scandinavia, esp. ch. 6 and 9 . 

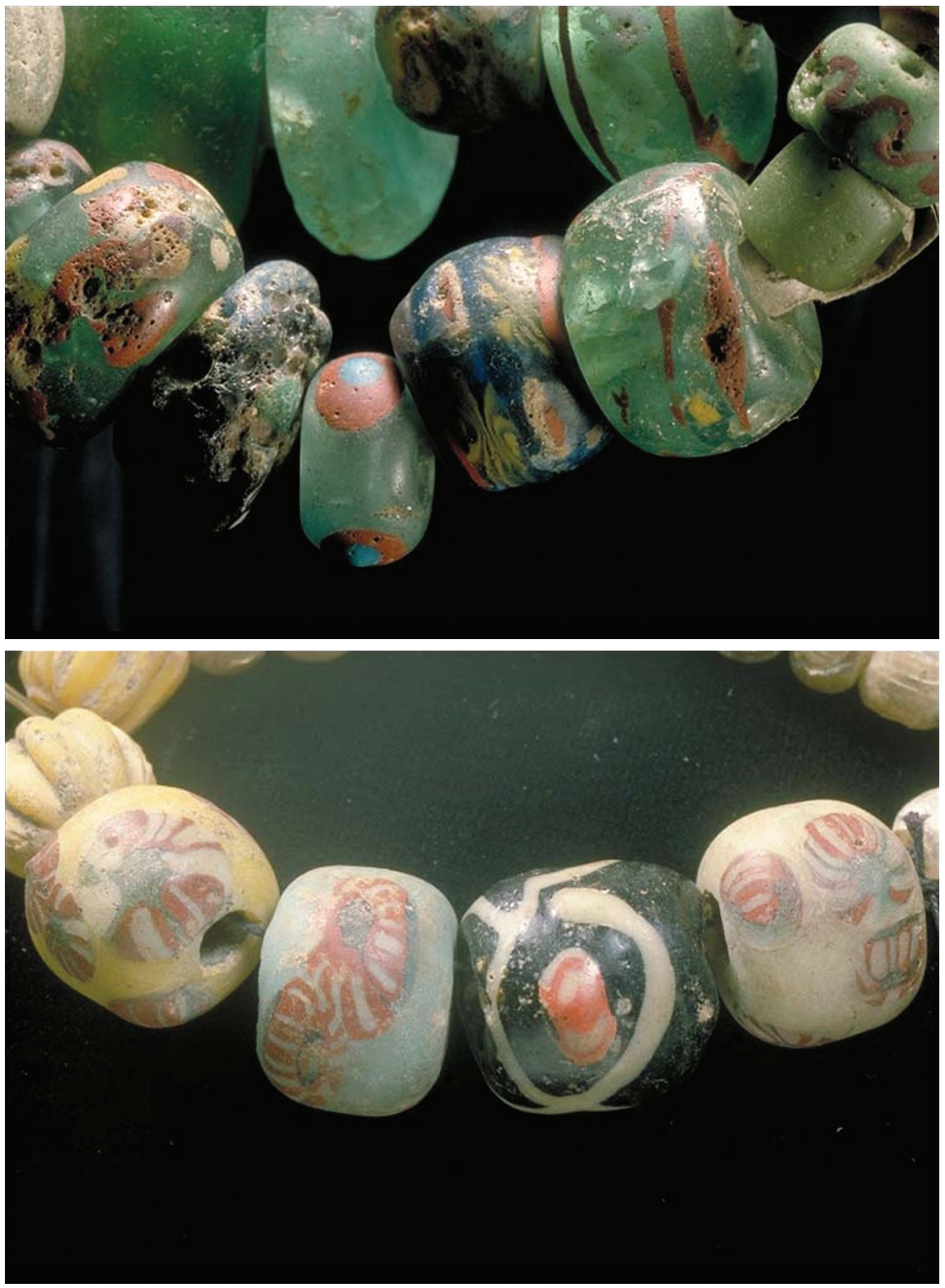

FIG URE 10.1 Scandinavian Viking-Age beads from Birka, Sweden. From graves $55^{\circ}$ (top) and 1067 (below). Inventory Nos Shm 3400oBj55o (Top) And Shm 3400oBj1067 (Below). ${ }^{22}$ SOURCE: SWEDISH HISTORY MUSEUM.

$22 \mathrm{SHM}+$ number $=$ inventory number in the Swedish History Museum, Stockholm. 
market-dependent. ${ }^{23}$ The dictum "money does not only have economic functions" has therefore been strongly felt by archaeologists for several decades. It is still useful to remind oneself of these thoughts, perhaps especially when it comes to coins in archaeology, but the perspective has also been criticized for downplaying the economic dimensions too much and for leaning more on ethnographic accounts than on archaeological data. ${ }^{24}$ Still, it does not result that archaeologists in this way try to eliminate economy from the past, just attempt to find better-informed ways to identify and discuss it.

Coins presuppose the existence of a state or strong ruler, organized production, and a multi-purpose objective, components that cannot always be ascertained for pre- or proto-historical societies. Therefore, many archaeologists seem to prefer a broader study of "money" or "currency" rather than one of coins. They use coins mainly for purposes of dating different archaeological contexts, treated on an overall level or simply left aside to specialists (numismatists). Although there are examples of pre- and proto-historical coinage (such as that of the Celts), coins were most often produced in literate societies and often in themselves - through their inscriptions - are evidence of the existence of written culture. In, e.g., Japan and Northern Europe, the advent of coinage took place in the medieval period or its chronological equivalent, but in, e.g., China and Southern Europe, it started many centuries earlier. In effect, coins belong not to one specific chronological period but rather to a certain type of society. Proper coins thus belong mainly within the archaeological subdiscipline of Historical Archaeology, which studies both written and material sources and therefore primarily classic, medieval, and modern societies.

As we enter into the Middle Ages, however, the presence of written sources seems to be of some consequence even for archaeological research. Humans and societies appear more directly comprehensible and the content of texts is often given more weight or explanatory value than the sometimescontradictory material evidence. As a result, someone working with, for example, pre-Roman Britain or medieval Scandinavia (which is this author's home camp) may experience how the past, in scholarship, undergoes a rapid process of transformation. Within a time-frame of perhaps 15 o years (in the Scandinavian case, $c$.A.D. 1000 to 1150 ), the past changes from a fairly mystical place, investigated through archaeology, anthropology, history of religion, and ethnographical analogies, into a putatively illuminated and rational society. The latter may be examined using a rapidly increasing body of foreign and domestic

\footnotetext{
23 Neale, "Monetization, commercialization, market orientation, and market dependence", pp. 25 and $27-28$.

24 Haselgrove and Krmnicek, Archaeology of Money, pp. 2-3.
} 
written sources (among which we may include coins) as well as a wealth of archaeological and art-historical sources (among which we also may include coins!) whose shapes seem more familiar and whose meanings seem more directly comprehensible to us today. This has profound consequences also for the study of money and coins: the pre-historic means of exchange "must" always be "money" or "currency", even if the object in question is a coin. The historically situated coin, instead, is regarded primarily as a monetary instrument, even when we find it hoarded, affected by secondary treatment (such as folded, or pierced for wearing) or used in ritual ways (such as offered into a saint's grave), as the historical society is considered to have been rational. The underlying assumption seems to be that once enlightened about the economic possibilities of coinage, a society and its individuals could not turn back from "rational" economic behaviour.

This, presumably, goes back to the "historical" dimension of coins, which has been a prominent feature of their study ever since the Renaissance, and to which many of the established numismatic research issues are tied. Indeed, coins, through their portraits and inscriptions (among other features) name rulers, indicate titles and years, help to establish successions of monarchs, indicate that individuals or states held minting rights, and help us find out many other facts that contribute to our understanding of past societies. ${ }^{25}$ These are very "historical" research issues, and different from archaeological ones. Increasingly, however, the archaeological perspective, to which I will return in a moment, has gained ground within coin studies. This probably has to do with several factors, two of which immediately spring to mind. The first has, again, to do with archaeological scholarship itself and with the development of the branch or discourse of Historical Archaeology since the 1950s. ${ }^{26}$

"Historical Archaeology" encompasses scholarship and archaeological practice that deals with material remains and text sources together, or with material remains from a society which produced and used domestic text. It thus includes cultures from ancient Mesopotamia via pre-Columbian Mesoamerica and the European Middle Ages to colonial societies like 19th-century Australia, and is in this sense a much broader term than, e.g., "Medieval Archaeology". What it comes down to is not the precise place, time, and issuer, but the nature of the investigated society and of the available sources - objects and texts. This perspective and methodological stance offers theoretical and methodological

\footnotetext{
25 Cf. chapters 1, 8, and 13 in this volume.

26 Andersson, Scholkmann, and Christensen, "Medieval archaeology at the outset of the third millennium"; Andrén, Between Artifacts and Texts; Little, Historical Archaeology; Orser, "Introduction".
} 
openings to approaching coins from angles of relevance for archaeological issues and to treat them as a category integrated with a whole range of items of material culture. ${ }^{27}$ Thus, research questions deriving from archaeological contexts have gained prominences over several decades: for example, how, why, where, and by whom coins were used in early churches ${ }^{28}$ or in other ritual contexts. ${ }^{29}$ Research objectives derived from general and current archaeological debate, such as studies of "materiality", "agency", "object biography", or "entanglement" have recently also been explicitly applied to numismatic material. ${ }^{30}$ It seems that archaeologists, while acknowledging the expertise of numismatists, are now discovering aspects of the coin material that may be considered from an archaeological perspective.

The second factor for why the archaeological perspective has strengthened within coin studies is, I suggest, that historians and numismatists have a need for and interest in contextual dating of coins, in particular when it comes to groups of coins where the issuer is anonymous or the inscription is unreliable (e.g., imitative coinages). Although there are numismatic methods that may help solving such difficulties - in particular technical studies of weight, metal content, or dies, and considerations of the iconography - it is usually vital that additional indications can help to provide some fixed points, in particular as absolute dating is concerned. As archaeological method has become more multifaceted and increasingly finely calibrated, its investigations have become of more use and interest to historians and numismatists, while traditionally it was often the other way round (numismatists providing datings for archaeological contexts). Although there are issues to solve, including differences between scientific and numismatic dating methods, ${ }^{31}$ the interest today is mutual and the need to understand each other's methods and issues apparent to all involved.

It results that archaeologists now seem to better understand the value of coins for other purposes than dating, and feel freer to work with them out from

27 Cf. Andrén, Between Artifacts and Texts, pp. 179-83.

28 E.g., Dubuis and Frey-Kupper, Trouvailles monétaires d'églises; and Gullbekk et al., Use of Money.

29 E.g., Burström and Ingvardson, Divina Moneta; and Haselgrove and Wigg-Wolf, Iron Age Coinage and Ritual Practices.

30 Audy, Suspended Value; Carr, "Coins, crests and kings"; Ciric, "A secondary use of Roman coins?"; Codine-Trécourt, Les monnaies mérovingiennes; Corcoran-Tadd, "Is this the gold that you eat?' "; Herva, Nurmi, and Symonds, "Engaging with money"; Kemmers and Myrberg, "Re-thinking numismatics"; Krmnicek, "Das Konzept der Objektbiographie"; Myrberg,"The colour of money"; Myrberg, "The hoarded dead".

$31 \quad$ E.g., Archibald et al., "Numismatics and the chronological models". 
methodology, theory and research objectives derived from general archaeology. Old school numismatists and historians may find some of these studies peculiar or beside the point, but largely accept them as valid. All in all, my perception is that in the last few decades these two factors have greatly increased the general understanding of the multifaceted functions of coins and money: not only medieval ones, but more widely.

\section{The Seminal Role of Numismatics and Coins within Archaeological Method and Thinking}

Coins have in several distinct ways been particularly useful to archaeological and historical scholars and in a few circumstances had a decisive impact on the history of archaeology. To start with, it was recognized at an early stage that coins were of particular value for inquiry into the past. Not only are they less destructible and altered by time than many other types of ancient remains, but they are also found in a multitude of places, they are numerous and varied, and they are not as easily falsified and adulterated as are texts. ${ }^{32}$ For these reasons, and because coins fire the imagination and are easily collected, they were one of the most cherished components of early collectors and antiquaries in the building of the archetypical private museum, the Wunderkammer or cabinet of curiosities. Alain Schnapp illustrates a section on the transition from antiquarianism to archaeology proper with several engravings of early antiquaries and numismatists; most include coins and medals, underlining coinage's and coin collectors' fundamental roles in the process described (Figure 10.2). ${ }^{33}$

Importantly, these cabinets of curiosities were not only a pastime; the early collectors also contributed fundamentally to the building of knowledge around the collected objects.

In the 1810s, Danish antiquarian Christian Jürgensen Thomsen (1788-1865) was the first to work out and apply an archaeological three-period system (Stone, Bronze, and Iron Ages, the broad scheme that is still operated with today) within a museum collection and its exhibitions which opened in Copenhagen in 1819. The "three age model" was itself of ancient origins but was now put into practice. In so doing, Thomsen revolutionized the general understanding of chronology, demonstrated how the study of prehistory could be set on a scientific basis, and created a modern museum based in comparative

32 Jacob Spon (1673) and Ezechiel Spanheim (1664), both quoted in Schnapp, The Discovery of the Past, $184-85$.

33 Schnapp, Discovery of the Past, pp. 182-95. 


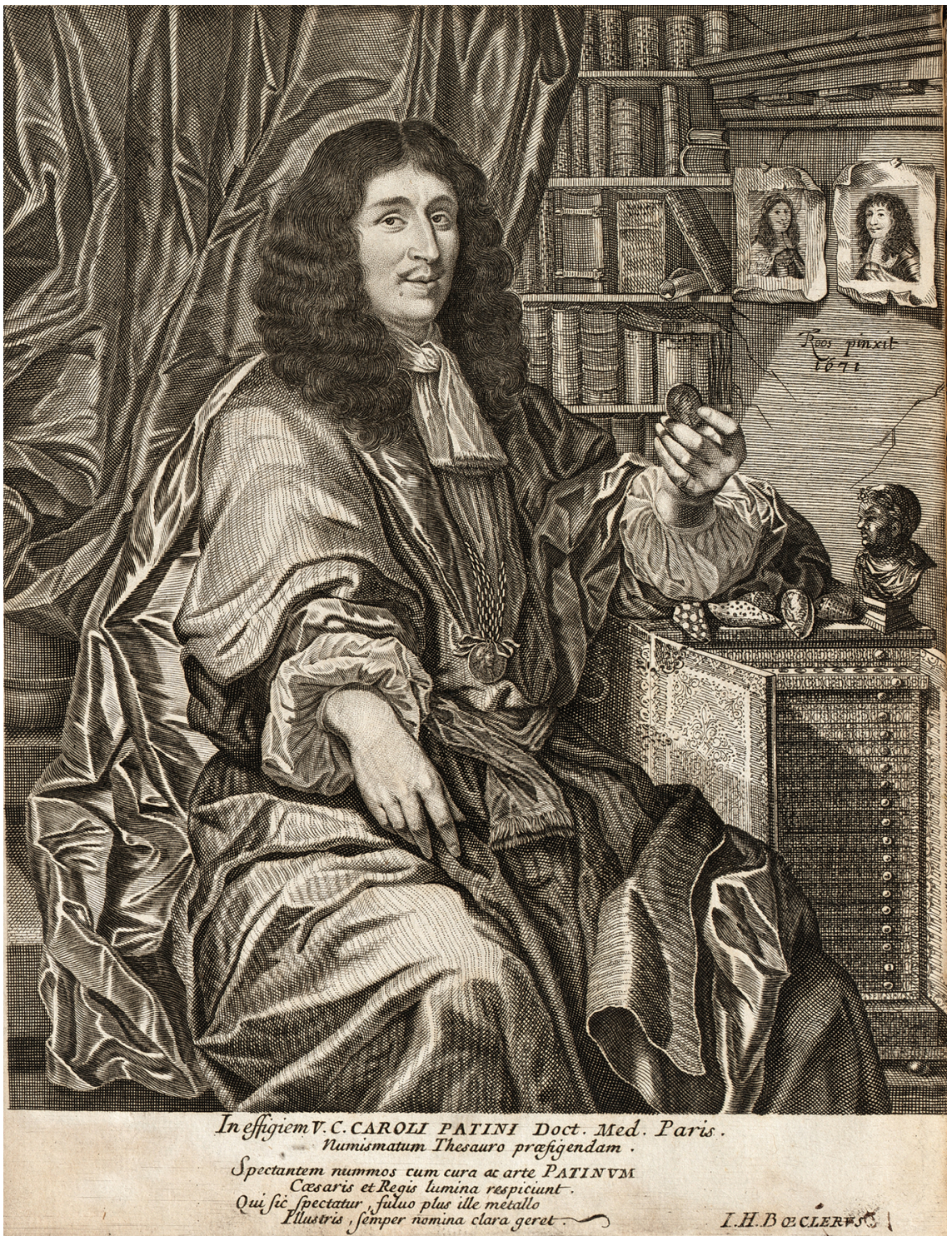

FIGURE 10.2 French antiquarian and collector Charles Patin, seated in front of his medal cabinet with a coin in his hand, a medal around his neck, and other art and naturalia items surrounding him. Engraving by Theodor Roos in Thesaurus Numismatum (Patin 1672).

SOURCE: BIBLIOTHÉQUE NATIONALE DE FRANCE, PARIS. 
archaeology and a genuine understanding of the more precise relations between objects rather than the amassed variation of a cabinet of curiosities. ${ }^{34}$ This he made out from his understanding of how to work comparatively with the content of finds, but this understanding was firmly rooted in his sense for details and the skills for typology and seriation which he had acquired through working with coins, the collecting of which had become a favourite pastime for gentlemen..$^{35}$ His findings and method were only published in $1836,{ }^{36}$ but were by then already well known among antiquarians and museum visitors.

John Evans (1823-1908), a collector and amateur archaeologist, successfully put his numismatic knowledge to use within other areas of archaeology as well. From coins and numismatic practices of study and publication he drew the methods and terminology for a comparative approach, which he applied to Palaeolithic artefacts. ${ }^{37}$ In his numismatic work, Evans showed keen interest in the latest discussions and advances and was open to new methods and modes of inquiry, such as using contextual data to situate coins chronologically, and recording find-spots in order to make indexes and maps of finds. ${ }^{38} \mathrm{Ev}-$ ans catalogued flint tools by noting differences and resemblances in material, form, or production technique, just as he would have done with his collected coins, ${ }^{39}$ and thus managed to transfer his methodology and understandings into a whole new field, which he in practice created. ${ }^{40}$ Nathan Schlanger asserts that the contribution of numismatics and coins consisted not only of the methodology, but also importantly a language (such as the terms "striking" and "wrought") and a system of analytical and uniform description..$^{41}$ Evans was also inspired by the accurate, detailed descriptions and depictions of coins, a technique he subsequently applied also to stone and bronze implements. His numismatic experience influenced his modes of interpretation and his method for authenticating artefacts from, e.g., "patina, weight, workmanship, and

34 Eskildsen, "The language of objects"; Schnapp, Discovery of the Past, pp. 299-301; and Trigger, A History of Archaeological Thought, p. 127.

35 Klindt-Jensen, A History of Scandinavian Archaeology, pp. 49-52 and 55-57; and Trigger, History of Archaeological Thought, pp. 122-27.

36 Thomsen, Ledetraad til Nordisk Oldkyndighet.

37 King, "Evans and the Roman coinage"; MacGregor, "Sir John Evans, model Victorian, polymath and collector"; Schlanger, "Coins to flint"; and Schlanger, "Series in progress".

38 Jersey, "Evans and ancient British coins", pp. 162-66; and King, "Evans and the Roman coinage", pp. 180-81.

39 Evans, "On the occurrence of flint implements in undisturbed beds of gravel, sand and clay"; cf. e.g., Evans, "On the date of British coins".

40 Schlanger, “Coins to flint", p. 466.

41 Ibid., p. 467. 
the manner in which it came into my possession".42 Evans's numismatic work on the development of coins was explicitly picked up by A.H. Lane-Fox Pitt Rivers, who applied it to the development of New Ireland paddles. ${ }^{43}$ Similar ideas of serial or typological development were soon firmly established within the archaeological community. ${ }^{44}$

The Palaeolithic assemblages that Evans worked with were to have profound impact on the general understanding of the time-depths of the Earth. His studies were thus part of a process of revolutionary re-evaluation of the history of mankind, which arguably was much longer than allowed for by biblical history. In this process, early archaeologists cooperated with geologists, zoologists, and palaeontologists, as understanding the formation of Palaeolithic sites out from a natural-scientific perspective was important for their archaeological apprehension. But the true driving forces behind the development of methods and of a chronology of artefacts and humans, and thus the establishment of high human antiquity, were antiquarianism, art, and numismatics. ${ }^{45}$ The work of Thomsen and Evans, two 19th-century researchers and numismatists, fundamentally changed archaeological methodology and the organization of collections, but also contributed to a total reconsideration of human history when the time-depth of humans and the globe was understood. In these processes, coins played a pivotal role.

\section{The Use of Coins within Archaeology}

As noted above, in the medieval period "money" mainly implies "coins" (as in "metal-based units of account"), although currencies such as butter and cloth are known to have been used in some cases. ${ }^{46}$ The following section therefore focuses on coins, but some examples will be drawn from time periods other than the medieval, when relevant for theoretical and methodological issues. This section will review some of the fundamental conditions for archaeological use of coins, and end by considering a few examples of coin studies chosen

\footnotetext{
42 Evans, "Errors respecting the coinage of the ancient Celtic kings of Britain", p. 164; Schlanger, "Coins to flint", pp. 468-69; and Schlanger, "Series in progress", pp. 351-52.

43 Schlanger, "Series in progress", pp. 358-59.

44 E.g., Montelius, "Typologien eller utvecklingsläran tillämpad på det menskliga arbetet”.

45 Trigger, History of Archaeological Thought, pp. 135 and 138; Schlanger, "Coins to flint", pp. 475-76; and Schlanger, "Series in progress", p. 343.

46 Gullbekk, "Natural and money economy in medieval Norway".
} 
from an archaeological point of view, as well as of studies that successfully integrated archaeology and numismatics.

\section{Coin Finds and Archaeological Method}

Federico Barello points at the vast numbers of coins found on almost every archaeological site in the Mediterranean area as a fundamental reason for why archaeologists need to acquire at least some basic understanding of the material and the ways it may yield information. ${ }^{47}$ This applies in particular to scholars studying the ancient period, when base-metal coinage was made and used on a large scale. Although the former Greek and Roman areas are perhaps better furnished with coin finds than most, the proposition holds true everywhere that coins may be expected to turn up. But from an archaeological point of view, coins differ from each other not only in what they are but perhaps even more in how they are found. The type of find, and the way it was retrieved, is decisive for what can be said about the coins and what they can be used to discuss. Archaeologically speaking, there are three basic categories to consider: coins which are stray and un-stratified, those which were individually accumulated over time but are incorporated into a larger context (like finds from a market square, a ritual site, or an offering well) and those which are part of a well-defined event such as a hoard or a grave (although the contents of either of these may well have been collected over a longer period of time before being deposited). These categories of finds may be used for different types of investigations and are often retrieved with very different methods and degrees of accuracy. Grierson, for the same reason, distinguished between stray finds, "location finds" (a gravefield, Roman villa, etc.) and "area finds" (a larger tract of land), and between single-finds, accumulated finds, and hoards; ${ }^{48}$ although departing from a historian's point of view they mainly coincide with the categories noted above.

The stray- or single-find, or "casual loss", 49 is usually considered to hold the least scientific value, as it cannot really be related to other features. Yet it can be significant purely because of its presence: for example, by indicating coin use or even degrees of monetization, in particular if it is possible to use or compare significant numbers. Jens Christian Moesgaard used un-stratified detector finds from Danish rural areas to locate medieval settlements and, further, to demonstrate that rural use of coin was much more commonplace in the Middle Ages than previously thought when drawing mainly on data from 
churches and documents..$^{50}$ There may be several reasons for a coin to turn up as a single-find, and the category likely lumps together coins which derive from many different uses, scattered deposits, or crumbled structures..$^{51}$ Old, foreign, or otherwise odd stray coins could derive from amuletic use, like the many examples of stray pierced and unpierced coins from U.S. archaeological sites associated with enslaved African Americans, who attached them to clothes or carried them in their shoes as charms. ${ }^{52}$ In the U.K., a large number of stray-found medieval Byzantine coins were probably brought to the island by British travellers as souvenirs over the last two centuries. ${ }^{53}$ Such secondary or prolonged uses of an un-contextualized coin cannot be proven through archaeology, but the area where they are found might sustain some reasonable interpretation, and the examples illustrate that there are many possibilities to evaluate before casting the single-find aside as un-informative.

The particular value of an accumulated find (or a "series of single finds" ${ }^{24}$ ) is its diachronic scope combined with a spatial dimension. An accumulated find may tell of use-patterns on a site and also of changes over time in the practices or of the character of the used material. Ideally, in order to truly understand their use, all accumulated coins should be clearly associated with layers and/ or features on the site. For example, Haselgrove considers stratified coin sequences to be the best, perhaps the only way to understand the chronological development of Iron Age coinage in Gaul and its interplay with Roman coins, and refers the new possibilities for dating to "large-scale archaeological excavations at Iron Age settlements and especially religious sites, and widespread use of metal detectors".55 But even when coins are not stratified it may still be possible to, for example, assess them more generally to identify clusters and patterns on different scales, or discuss the composition of the regional coin stock. ${ }^{56}$ Concentrations of coins may indicate the previous position of features, such as removed altars in a church, and the dating possibilities of coins may provide approximate start or end dates for the use of a site as well as information on fluctuations in coin use, production, or influx from other areas. The quality and degree of accuracy in a survey, excavation, and documentation are, obviously, key factors for what can be done.

50 Moesgaard, "Bønders møntbrug i middelalderen. Hvad detektorfundne mønter fortæller".

$5^{1}$ Cf. Krmnicek, "Coins in odd context".

52 Fennell, "Conjuring boundaries", pp. 286-87; and Russell, "Material culture and AfricanAmerican spirituality at the Hermitage", p. 7 .

53 Naismith, Medieval European Coinage, p. 36.

54 Heijne, Särpräglat, pp. 44-45.

55 Haselgrove, "The development of Iron Age coinage in Belgic Gaul", p. 111.

56 E.g., Hodder, "Distributions of Iron Age material”. 
Churches represent a well-defined ritual context that appeared during the medieval period and many of them have been in use for more than a millennium. Through accumulated church finds, it is possible to study a long-term and continuous use of coins by a whole population, not only or mainly the nobility, merchants, and burghers who come through in written sources. Scandinavian and Swiss churches contained an unusually large number of coins - valuable from a statistical point of view - due to their use of wooden floors. Studies relating to this type of find have included processes of monetization, how the use of money spread geographically, and also the relationship between coins used in towns and in the countryside. ${ }^{57}$ As churches in many cases are still in use today, few coins were left in their original positions. But even if the layers were disturbed, it is still possible to recover information through careful registration of the coin's position in x-y-z axes (three-dimensionally horizontal and vertical), through sieving the fill and vacuum-cleaning spaces such as chambers in the belfry towers.

Many settlements and towns were occupied long before the Middle Ages, but their accumulated finds are of particular interest for the same reason as those in the churches: we can observe continuous use by the whole population, which may contrast with what meets us through written evidence. Whereas medieval towns may offer fabulously thick cultural layers which preserve archaeological data very well, the rural settlements normally offer less of that. Excavation is still important for our understanding of those sites, but extensive methods such as geophysical analyses, phosphate mapping, and metal-detecting may be of greater initial use in pinning down the extent and character of sites.

For more narrowly defined contexts, like a building, a posthole, or a grave, coins may provide a dating, but this is far from straightforward. The coins in a grave were often clearly selected for the purpose and usually do not represent the normal coin stock in use unless they were truly kept together to be used for everyday purposes. As much as the grave represents a single deposition event (albeit one that may have been protracted) rather than an accumulation over time, the time-span of its contents may be considerable and must be taken into account. For example, it makes a great difference if a coin found in a grave was in a purse with other coins (more likely to be fairly contemporary with the burial), strung on a necklace (more likely to be considerably older than the burial), or part of a small hoard deposited near the feet. Roman coins found in considerably later Anglo-Saxon graves as pendants were interpreted as part 
of an important aspect of the costume for young and adult females, due to the antiquity of the objects that connected them with a distant past. When they were without means of suspension but included in purses it was with other items of a ritual, rather than monetary, character. Still, in some graves the Roman coins were found with scales and weights, suggesting that they, too, were used as weights. ${ }^{58}$ In yet other Anglo-Saxon graves, Roman coins were found in positions that indicate that they were placed there by mourners, rather than being part of the costume or of the life-equipment of the deceased. ${ }^{59}$ These cases exemplify how the close context and the precise relation between finds is essential for the interpretation of the single artefact, and how important detailed recording and documentation is, since it will forever provide the framework for interpretational possibilities.

Similarly, a coin found under the threshold of a building may be assumed to predate it and - particularly where the rather common habit of making "construction offerings" is known to have been practised - it may even date the very time of construction (although one would like corroborating data from, e.g., a dendrochronological sample to argue this with more certainty). But coins from the bottom of postholes may either have been put there at the time of construction or be later infill. To give an example, in the Norwegian stave church of Høre, one coin from a posthole may with certainty be regarded as a building's offering, since it was found under the bottom stone. ${ }^{60}$ On the contrary, in the Swedish church of Arby, the coins found in the postholes of an underlying early wooden church dated not from the construction of that church but from the period when it was dismantled. In the latter case, the coins derived from use in the new nave (built around the early church), and ended up in the early postholes only when the posts were pulled from the ground. ${ }^{61}$ It is not unusual that the earliest coins to appear in medieval churches are considerably older than the presumed building date, in which case it must be evaluated whether they derive from, e.g., underlying graves. The earliest coins may also be foreign or pierced to be used as spangles. In those cases, amuletic uses such as those suggested for "odd" coins in African American contexts as described above come to mind, rather than their being particularly useful for purposes of dating.

The most spectacular type of coin find is usually the hoard or deposit, where numbers of coins, and often other artefacts, are found positioned in a way that

\footnotetext{
$5^{8} \quad$ Eckardt and Williams, "Objects without a past?", pp. 149-53.

59 King, "Grave-goods as gifts in early Saxon burials", pp. 230-31.

6o Risvaag, "Echoes of the mother church in a remote valley".

61 Andersson and Svennebring, Arby kyrka.
} 
makes it clear that they were deposited together. The material may be more or less homogenous: it is not unusual to find thousands of coins of more or less the same type in a hoard, but there are also very small deposits consisting of just a few specimens, and others include objects from very different areas or coins with a very long chronological scope. Hoards represent a single deposition event although the content may be diachronic, and were generally intentionally collected from a certain pool of objects and with a certain purpose (for economic purposes in, e.g., a lost purse, or intended for long-term deposition with savings or ritual objectives). There has been long-standing debate about the reasons for depositing coins and other objects in this way and a basic distinction is often made between economic (savings) hoards and ritual hoards. The latter is as much a numismatic as an archaeological issue to be determined from the composition of the find; the archaeologist can contribute with contextual data, such as the understanding that some hoards are structured in a way that echoes the content of contemporary graves. ${ }^{62}$

Archaeological methodology is, however, of particular use when it comes to careful excavation of hoard contents, as has been done in a few cases. ${ }^{63} \mathrm{In}$ early discoveries, little attention was paid to the context of the finds, and often the coins were taken out immediately without expert supervision. But even today different circumstances may cause the retrieval of hoards without archaeological surveillance; it is a great pity when this happens. Through studies like those mentioned above, it has resulted that there is a great deal more to understand from hoards than only which coins and objects are included. The results demonstrate in some cases sorting of coins after origin, or that coins were laid down as physical parcels (not only in the numismatic "cluster" sense of the word). In some cases, seeds and other organic material were included (Figure 10.3), or coin layers of a hoard separated with intact jewellery.

The methodology is expensive but should be further developed in order to understand better the exact circumstances of the hoarding process - e.g., if it was all deposited at one time (perhaps hidden in haste, or meant to stay permanently where it was offered) or if it was added to over the years (the owner intending to use all or part of it from time to time, or to "reactivate" it as an offering). In such cases, archaeology may contribute also to the understanding of mechanisms, practices, and ideas behind the deposition. The

62 Kilger, "Kombinationer av föremål"; Myrberg, "The hoarded dead"; Myrberg, "The social identity of coin hoards"; and Thunmark-Nylén, Die Wikingerzeit Gotlands, pp. 456-58.

63 E.g., Brisholm and Rispling, "The Häffinds IV hoard"; Carlsson and Karn, "Att gräva ut en silverdepå ..."; Herrmann, Ralswiek auf Rügen; and Kaenel et al., Der Münzhort aus dem Gutshof in Neftenbach. 


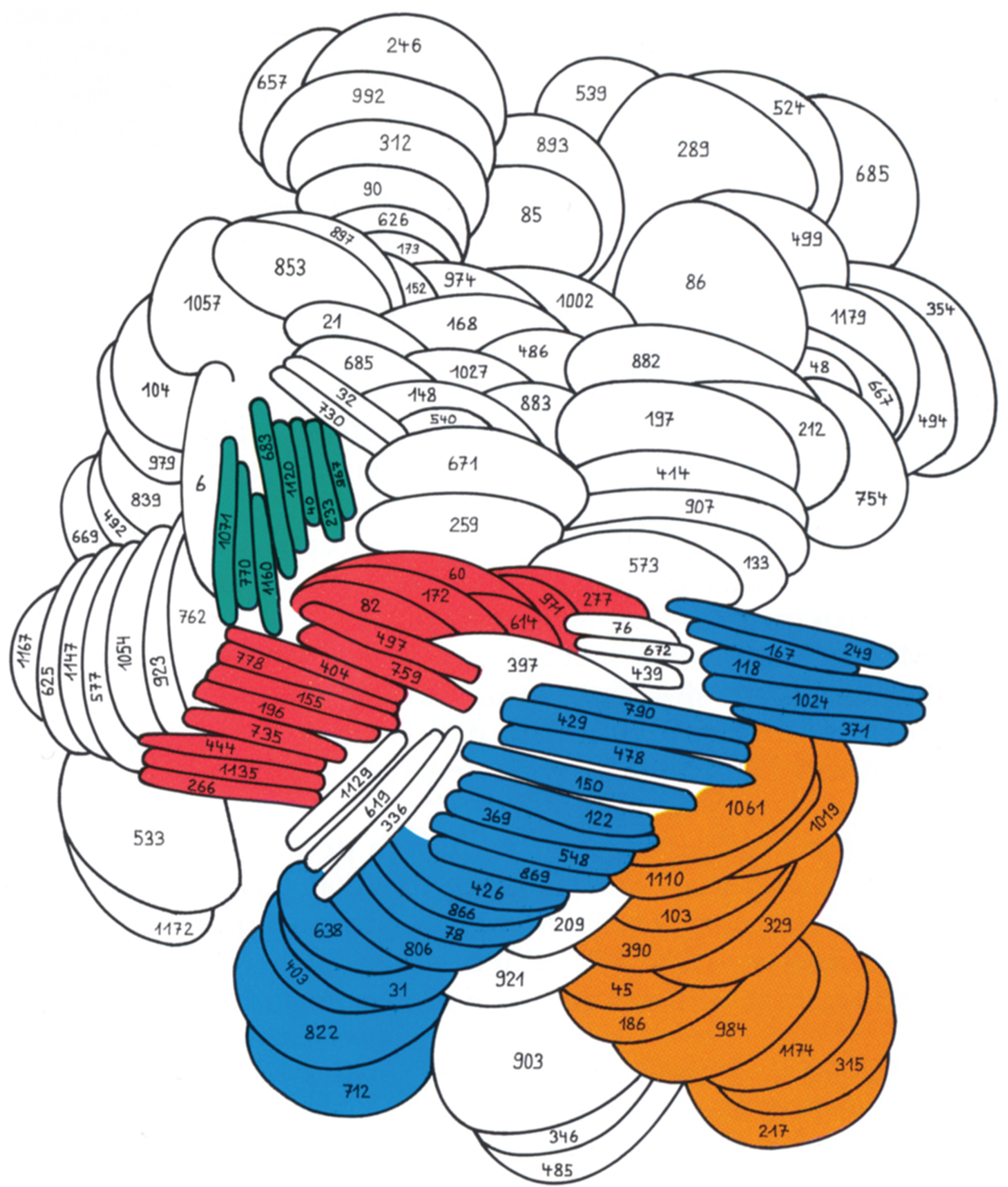

FIGURE 10.3 Reconstruction and documentation of a hoard from Neftenbach, Switzerland. The coins were deposited in a bronze jug, some singly and some wrapped into rolls, covered by cloth and hidden below the floorboards of a building. Mixed with and on top of the coins was foxtail millet.

AFTER KAENEL ET AL., DER MÜNZHORT AUS DEM GUTSHOF IN NEFTENBACH, FIGS. 45 AND 51.

archaeological interest for social-anthropological monies discussed earlier in this chapter has also fuelled the debate on a theoretical level, pointing towards alternative concepts of wealth and economy which may shed light on the hoarding phenomenon. 


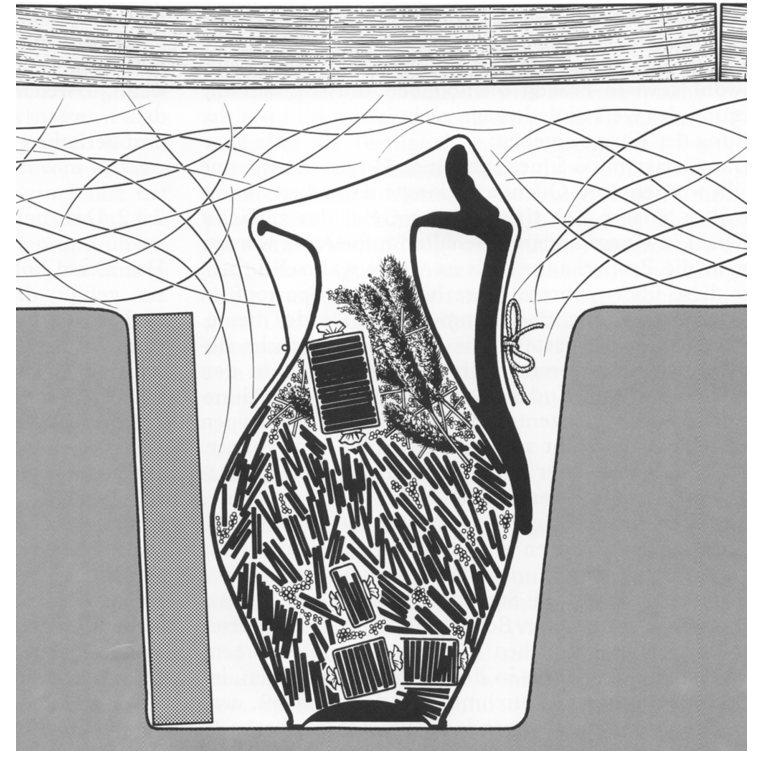

FIGURE 10.3

\section{Examples of the Fruitful Interplay between Archaeology and Numismatics}

There are certainly examples of coin types being known from written records that cannot with certainty be identified in the material record, or where coin volumes stated in writing are hard to match with the finds. ${ }^{64}$ There are thus limitations to the archaeological approach to coins. But coin finds may also provide evidence where written sources remain silent, by, for example, telling us about rulers we did not otherwise know or demonstrating contacts between areas. Some of the coins found in Scandinavian hoards are virtually unknown in their areas of origin (Figure 10.4). ${ }^{65}$

Through archaeology, new finds may also show a more complex material reality than that derived from the evidence of written sources, even contradicting it. For example, many instances show how coins had parallel use as noncoins (as ritual payment, amulets, etc.). Martin Allen recounts how around 100 coins were found when Archbishop Scrope's tomb in the York Minster was excavated in 1844, probably devotional offerings in and on the archbishop's grave. ${ }^{66}$ Claudia Perassi reports from archaeological investigations into five

64 See, e.g., Gullbekk, Pengevesendets fremvekst og fall, English summary pp. 306-17.

65 See, e.g., Rispling, "Spännande mynt i Spillingsskatten".

66 Allen, "Coins and the church in medieval England". 
different sites from the $5^{\text {th }}$, 6th, and $7^{\text {th }}$ centuries that coins were evidently used in connection with the baptismal fonts, perhaps at baptisms, despite the explicit ban on such practises by church officials. ${ }^{67}$ Lucia Travaini, ${ }^{68}$ Mark Hall, ${ }^{69}$ and Richard Kelleher, ${ }^{70}$ among others, cite examples of medieval coins being inserted into graves and foundations or sewn into clothes as offerings or amulets. ${ }^{71}$ The medieval coins found in Scandinavian and Swiss churches were in all likelihood offered either on altars or in offering boxes and ended up in the fill of medieval burials and later burial chambers after falling onto the floor and disappearing under it. ${ }^{72}$

In short, numerous archaeologically retrieved coins point out clearly how coins were used for purposes other than the intended economic ones, which are most prominent in written sources and contemporary documents. Christoph Kilger connects the high number of coins in the northern part of a Gotlandic church not to monetization but to an impressive fresco on the northern wall of the nave, where money may have been offered as part of the ritual practices performed in front of it. He also connects the higher degree of fragmentation of the coins found in this area to movement, kneeling, and trampling during the rituals rather than to a need for smaller denominations (and thus a higher degree of monetization, as would often be the interpretation when mainly statistics and numbers are considered, rather than an examination of the physical objects). Archaeological considerations of taphonomy (processes of wear and decomposition) were here vital for the discussion. ${ }^{73}$

A number of studies have also investigated coin use in a monetary sense and benefitted from archaeological data. Studies of monetization and coin output have long interested (economic) historians but are difficult to conduct conclusively from written sources alone, meaning that coins and coin finds have important roles to play. We must consider the use of coin in medieval Europe to be extensive, ${ }^{74}$ although its intensity varied between areas and periods. The impressive numbers of coins, tributes, and revenues quoted by Grierson, Jacques Le Goff, and Peter Spufford for central European

67 Perassi, "Coins and baptism in late antiquity".

68 Travaini, "Saints and sinners"; and Travaini, "Saints, sinners and ... a cow".

69 Hall, "Money isn't everything"; and Hall, “'Pennies from heaven'”.

$70 \quad$ Kelleher, "Pilgrims, pennies and the ploughzone".

71 Hall, "Money isn't everything". Compare to Thordeman, "Myntfynden i Korsbetningens massgravar".

72 Cf. Gullbekk et al., Use of Money.

73 Kilger, "Moving money, ritual money".

74 See Grierson, Coins of Medieval Europe; Grierson, "Commerce in the Dark Ages", pp. 77-79; Le Goff, Money and the Middle Ages, pp. 36-47; and Spufford, Money and its Use, ch. 4. 

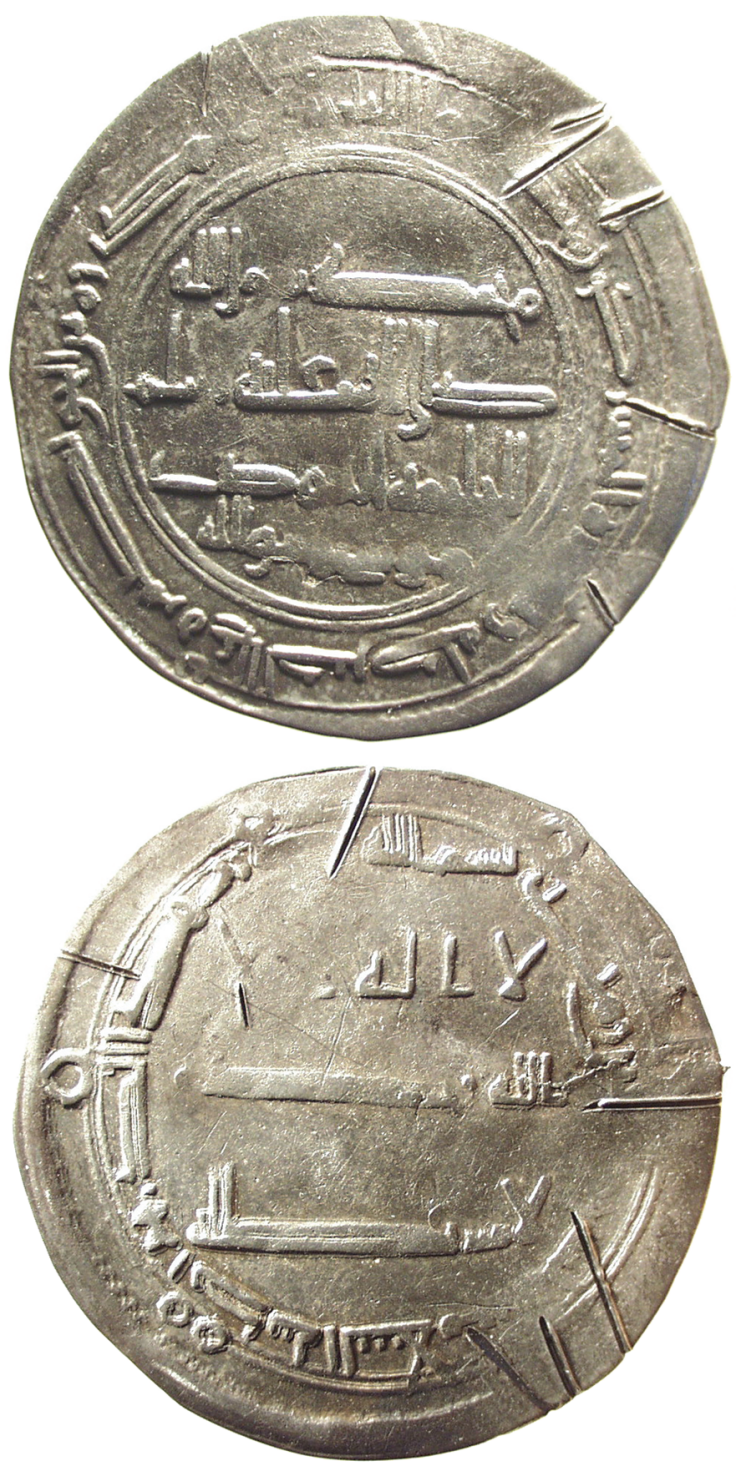

FIGURE 10.4 A Khazar coin inscribed "Musa rasul Allah" (Moses is God's messenger), found 1999 in a hoard from Spillings, Gotland, Sweden. The coin (dated $c .837$ ) is unique and the only physical proof of the Khazars' conversion to Judaism before A.D. 8oo.

SEE RISPLING, "SPÄNNANDE MYNT I SPILLINGSSKATTEN".

PHOTOGRAPH: KENNETH JONSSON. SCALE 3:1. 
areas such as France, Germany, or Italy were not to be matched by many other parts of the continent and its adjacent areas for a long time. One of archaeology's particular assets is the ability to provide more detailed and differentiated data for different regions, including those where the written evidence is scant. For example, Henrik Klackenberg's seminal study of monetization in Sweden, ${ }^{75}$ based on accumulated finds in churches, indicated that despite domestic coinage being introduced more than two centuries before, coins were used to a significant extent only after c.A.D. 1250 (although it should be noted that this was even at that point in a very particular setting, closely tied to the ideas and needs of the central Church). From the major part of contemporary settlement layers and towns, the evidence of coin use is even scantier.

Moesgaard has used metal-detector finds to demonstrate a change in the use of money in the Danish countryside and that use of coins was more common in medieval rural settlements than previously thought, as referred to above. ${ }^{76}$ In a subsequent study, ${ }^{77}$ he investigated how data related to the "coin profiles" (composition) of church finds deriving from investigations with modern metal-detectors on abandoned, unexcavated church grounds. Old metal-detectors were not very effective at finding small, thin coins like medieval bracteates, and the results from such early surveys were therefore too random to be entirely comparable. Modern detectors are able to pick up signals from very small and fragile coins, which opens new possibilities for metal-detecting on sites such as abandoned churches with less need to excavate (although comparisons show that sieving soil still increases the numbers found). Combining the two studies, one important conclusion is that the typical small medieval bracteates, often thought to represent the breakthrough of a monetary "market" use of coins, are surprisingly more common in churches than in settlements. Since these coins, as demonstrated in the second study, can be found with detectors, there is no reason to believe that this overrepresentation is due to detector issues, and Moesgaard's studies thus point towards some selective process for either the settlement or the church context. It could, in consequence, be suggested that church finds are more useful for discussing the start of coin use and the numbers used rather than payments in society outside of churches.

In the far more text-based Middle East, archaeology may make important contributions to the study of everyday economy and coin use, which is not

75 Klackenberg, Moneta Nostra.

76 Moesgaard, "Bønders møntbrug".

77 Moesgaard, "The redundant churches". 
in any way fully documented. In the medieval colonial Kingdom of Jerusalem (1099-1291), official coinages were supplemented by undocumented and unofficial lead token money. ${ }^{78}$ Several hundred such tokens have been found at about 30 locations within the territory, many in archaeological excavations. These secure contexts yield detailed information on how and where coins were used. Apart from one large hoard, the material consists mainly of stray and accumulated finds and some small hoards containing just a few coins. The finds were made in very different contexts: towns, fortresses, domestic areas, defensive structures, religious complexes, bath houses, mills, stables, and workshop areas, and in the capital as well as in smaller towns and in rural castles, manors, and farms. The use of these low-value lead tokens was accordingly not limited to any particular group of the community or special-purpose situation, but fulfilled an important role in daily economy by supplementing the official, high-value coinage. ${ }^{79}$ The lead tokens were locally produced, even for single estates, as demonstrated by several finds of moulds (Figure 10.5), ${ }^{80}$ and the designs were inspired by local coinages although many also derived from contemporary European coins and lead tokens.

Altogether, the evidence clearly shows, first, that the use of token money was brought to the Middle East with the European settlers and, second, that the colonial economy depended on unofficial solutions in addition to the official ones. The low-value lead tokens, on which the official and written narratives remain silent, are thus an important part of the archaeological evidence of the colonial project and the daily economy in the kingdom. Importantly, they also pinpoint a social class who depended on small transactions for their daily maintenance, and who rarely appear in the documents. ${ }^{81}$

Benjamin Luley has analysed the use of money on the archaeologically investigated Celtic site of Lattara with archaeology, and was able to distinguish the difference in practises before and after the Roman conquest. ${ }^{82}$ Pre-Roman layers yielded coins mainly from domestic contexts, along with a few even earlier hoards and building offerings. Numerous Greek (non-domestic) coins from floor layers and rubble indicate a use for everyday purposes, but not in the monetized way seen after the Roman conquest, when coins also started to appear in shop and workshop contexts. Luley suggests that the pre-conquest phase represents not a coin economy as such, but the use of Greek colonial coins as

\footnotetext{
78 Kool, "Lead token money in the Kingdom of Jerusalem".

79 Ibid., pp. 295-302.

8o Ibid.; Syon, "A crusader token mould from Akko".

81 Kool, "Lead token money", pp. 312-13.

82 Luley, "Coinage at Lattara".
} 


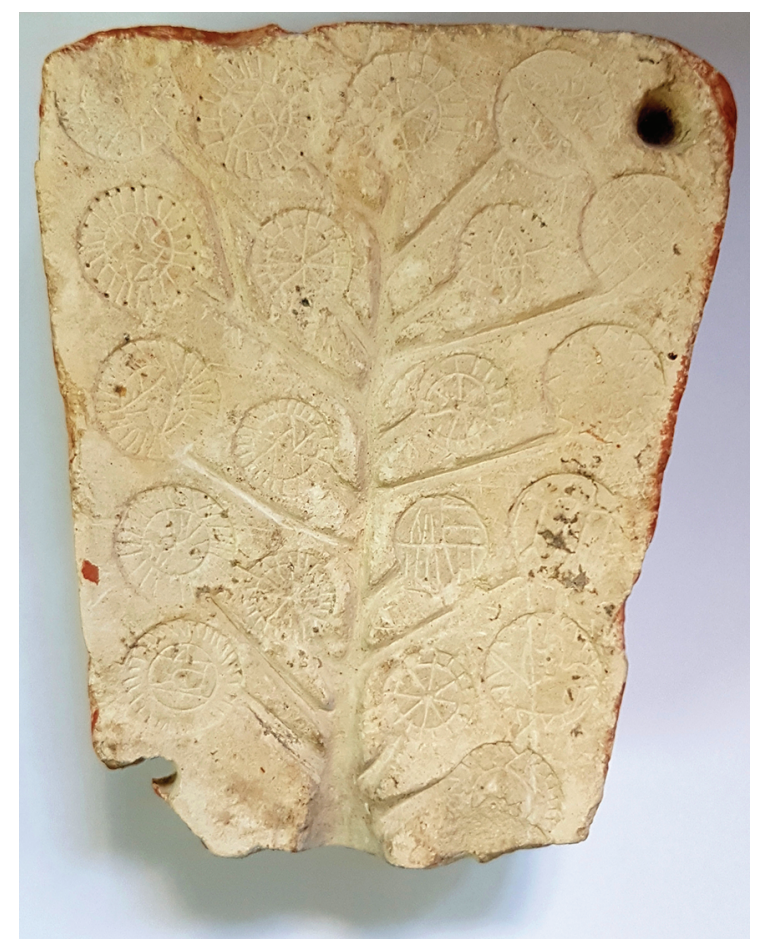

FIGURE 10.5 Lead token mould found in Akko, Israel (IAA 2002-294). SOURCE: ROBERT KOOL.

tokens to represent values in interactions between the Celtic population and Greek merchants: that is, as a kind of special-purpose money. One of the arguments for this is a clear preference for (yellowish) bronze or potin coins rather than "more valuable" silver ones, a preference that may be connected with early Celtic use of gold. Through considerations of both archaeological contexts and the character of numismatic material, Luley is able to trace a complex development from a first phase where a few foreign coins are used for votive offerings to a token period when they are used for barter and trade in domestic contexts, succeeded by an early monetary period when coins are found in more public contexts such as shops, and finally the advent of domestic coinage.

The great mass graves at Korsbetningen outside Visby on Gotland yielded not only the unique examples of medieval armour for which they are famous, but also quite a few coin finds. ${ }^{83}$ Through the excavations of, in particular, one

83 Thordeman. Korsbetningen; and Thordeman, "Myntfynden". 
mass grave on the 1361 battlefield, where particularly well-preserved clothes and attire made it possible to connect coins to individuals, Bengt Thordeman was able to considerably further the chronology of Scandinavian medieval coinage. From the size, position, and relative richness of this grave (compared to other, adjacent, graves), he argued that it was the last one dug, when corpses were in such a state that undressing them and searching for valuables such as coins and weapons was omitted. He was further able to conclude that in the haste, both Gotlanders and the attacking Danes were buried together, judging from the different coins in purses or stitched into clothes which were not in themselves nationally distinct. The presence of coins, and their numismatic qualities, was vital for the understanding of this historically very significant battle, and the archaeological methodology contributed vitally to the increased understanding of coin chronology.

A post-medieval example of a productive interplay between archaeology and numismatics is the case of the obsolete copper coinage that was used by the Virginia Company in Fort James, Virginia, at the beginning of the 17th century. ${ }^{84}$ These coins are now rare or non-existent in their original context (e.g., Ireland) but were found on the other side of the Atlantic where they were brought to be used as token money when they became obsolete in the area of origin. The use of token money in the colony was not known through written sources but was discovered during excavations in Jamestown. It was established that most of the tokens circulated before 1610, then declined quickly and had almost entirely disappeared by 1620 . From the following period, some specimens have appeared in settlements outside of Fort James and in Native American graves, indicating a third-phase use of the obsolete coins and tokens. ${ }^{85}$ Several types of coins and token money were used, including Dutch tokens, English "Touch pieces" and lead tokens, and Irish coins/tokens. These had to be exchanged for a "banknote" when traders and colonists left the colony and the note could then be cashed in for valid coin upon arrival in England, so there was no reason for travellers to bring the tokens back. The site also yielded the largest number of German Rechenpfennige (counters) found in the New World, but the author does not consider them as part of the tokens for use as money in the colony. ${ }^{86}$

Beverly Straube proposes that the numismatic material from Fort James testifies to a monetary scheme by the Virginia Company, meant to facilitate wage and goods payments within the colony, but one that was short-lived or

84 Straube, "Numismatic portals".

85 Ibid., pp. 192-96 and 199 .

86 Ibid., pp. 185-86 and 194-201. 
abandoned before it could be fully implemented due to hostile natives forcing the settlers to temporarily vacate the site. ${ }^{87}$ The numbers of coins and tokens found at this small colonial settlement were, however, not small $(167$, of which 140 were deposited between 1607 and 1610, and 500 Rechenpfennige), especially if measured against the numbers one would recover from any ordinary European contemporary context. (For example, the loss rate in most Scandinavian churches has been estimated at less than one coin every two years.) So however short-lived the scheme was, it must have been attempted seriously and may have played an important role while it lasted.

In this case, archaeologically retrieved numismatic data provided openings to a historical narrative on which written sources remained silent. The faraway and specific context also provided a material record that was partially different from what was known (in collections and archaeologically) from Europe, and brought clarity to several specific issues regarding the material itself. For example, some tokens could be re-attributed, one previously undated English halfpenny pattern could be dated, and an entirely new type of object was found, namely tokens to be presented at Royal "Touch" ceremonies. ${ }^{88}$ One trial plate of scrap copper retrieved from a well (dated to c.1608-1610) inside Fort James, where it was buried with coins and tokens, suggested rather surprisingly that the origin for the numismatic material was the Royal Mint. Straube suggests that the Fort James obsolete coins and tokens were in fact supplied by the Mint's master-worker, who was also a shareholder in the Virginia Company and the father of one prominent Jamestown colonist.

One final interesting example of successful interplay between archaeology and numismatic material is drawn from the 2oth-century Channel Islands. ${ }^{89}$ In this case, archaeological theory regarding object biographies and material culture in general, rather than excavations, provided the results. Gilly Carr investigates the shortage of small change in the occupied Channel Islands during the Second World War and how this came about despite the fact that six currencies (British, Guernsey, Jersey, French, and three German) circulated side by side. She concludes that the shortage was due mainly to two parallel processes. First, German soldiers used to send coins bearing the badges and crests of the Channel Islands home as souvenirs from the conquered land. Second, numerous coins were transformed into "trench art" by both Germans and locals, the latter using them as small items of resistance and identity. While

\footnotetext{
87 Ibid., p. 204.

88 Ibid., pp. 197-201; concerning the "Touch" ceremonies, see Farquahar, "Royal charities", Bloch, Les Rois thaumaturges, and Brogan, The Royal Touch.

89 Carr, "Coins, crests and kings".
} 
Germans favoured coins with crests, locals preferred the image of the king, but they were both made into similar objects, such as badges and cigarette lighters. ${ }^{90} \mathrm{~A}$ triumphant takeover of material culture for the occupants was instead a defiant and secretive statement for the occupied, who wore the coin-badges inside their lapels to flash as a signal to trusted friends and to communicate group solidarity. ${ }^{91}$

Interestingly, there are similarities between the German soldiers' fascination for Channel Island coins in Carr's study and the Fort James tokens. Although their first phase of use - and in this case, also their re-use as tokens - was of economic character, in both places the coins were subject to modifications and a non-monetary re-use which may have been rooted partly in a common interest in souvenirs and partly in the feeling that one was taking possession of the enemy's icons and identity. Like the coins from the Channel Islands which were brought or sent to Germany as souvenirs or trophies of war, many of the coins and tokens from Jamestown turned up in new contexts as they became status symbols (or lucky charms?) for Native Americans. The New World tokens were again re-contextualized when they eventually followed their owners into their graves, ${ }^{92}$ and the trench art and souvenir coins in many cases remain treasured family heirlooms. ${ }^{93}$

\section{Decoding Money through Archaeology}

This chapter has argued for the benefits of a close relationship between archaeology, coins and numismatics in several ways: by looking at how coins and money may be used within a theoretical and methodological archaeological framework; at coins as vital for archaeological research history; at coins as archaeological material; at the ways archaeology may contribute additional value to coin studies and vice versa; and finally at examples of the useful interplay among archaeology, coins, and numismatics with a few cases taken from different periods, locations, and research traditions. To develop the archaeological study of coins, and what could be called a "third space of coin studies" 94 in the intersection between archaeology and numismatics, we rely on good examples and illustrative case studies such as these to analyse and illustrate how coins

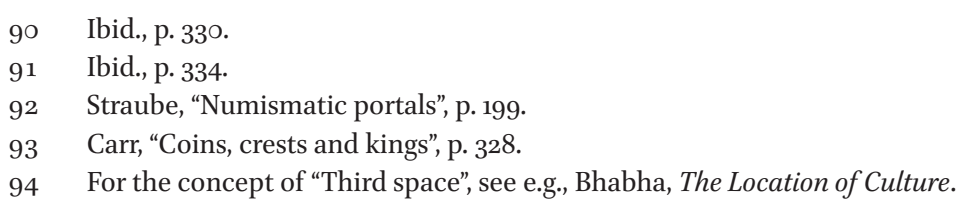


may be put to use for purposeful and thought-provoking inquiries into the past and present.

\section{Acknowledgements}

I am most grateful to Dan Hicks for once drawing my attention to Nathan Schlanger's research about John Evans and to Mats Burström for comments on a draft of this paper. For illustrations and permissions to publish them I thank the Bibliothéque Nationale de France (Figure. 10.2), Kenneth Jonsson, Stockholm University (Figure. 10.4), Hans-Markus von Kaenel, Goethe-Universität Frankfurt am Main (Figure. 10.3), Robert Kool, Israel Antiquities Authority (Figure. 10.5), and the Swedish History Museum (Figure. 10.1).

\section{Bibliography}

\section{Primary Sources}

Ibn Fadlan A., Kitāb ilá malik al-șaqälibah, as R.N. Frye (ed.), Ibn Fadlan's Journey to Russia: A toth-Century Traveler from Bhagdad to the Volga River, Princeton, 2005.

\section{Secondary Literature}

Allen, M., "Coins and the church in medieval England: votive and economic functions of money in religious contexts", in Burström and Ingvardson, Divina Moneta, 2017, 16o-73.

Andersson, H., Scholkmann, B., and Svart Christensen, M., "Medieval archaeology at the outset of the third millennium: research and teaching", in J. Graham-Campbell and M. Volor (eds.), The Archaeology of Medieval Europe, Vol. 1: Eighth to Twelfth Centuries $A D$, Aarhus, 2007, 19-45.

Andersson, K., and Svennebring, O., Arby kyrka. Södra Möre härad, Småland, Stockholm, 1989 .

Andrén, A., Between Artifacts and Texts. Historical Archaeology in Global Perspective, New York, 1998.

Appadurai, A. (ed.), The Social Life of Things: Commodities in Cultural Perspective, Cambridge, 1986.

Archibald, M., Bayliss, A., Hines, J., and Scull, C., "Numismatics and the chronological models", in A. Bayliss and J. Hines (eds.), Anglo-Saxon Graves and Grave Goods of the 6th and 7th Centuries AD: A Chronological Framework, London, 2013, 493-515.

Audy, F., Suspended Value: Using Coins as Pendants in Viking-Age Scandinavia (c.AD 80o-1140), Stockholm, 2018.

Barello, F., Archeologia della moneta: produzione e utilizzo nell'antichità, Rome, 2006. 
Bhabha, H., The Location of Culture, London, 1984.

Bloch, M., Les Rois thaumaturges: étude sur le caractère surnaturel attribué à la puissance royale particulièrement en France et en Angleterre, Strasbourg, 1924.

Brisholm, K., and Rispling, G., "The Häffinds IV hoard: a methodological experiment", Nordisk Numismatisk Årskrift 1985-1986 (1991), 39-52.

Brogan, S., The Royal Touch in Early Modern England: Politics, Medicine and Sin, Woodbridge, 2015.

Burström, N.M., and Ingvardson, G.T. (eds.), Divina Moneta: Coins in Religion and Ritual, Abingdon, 2017.

Callmer, J., Trade Beads and Bead Trade in Scandinavia ca. 80o-10oo A.D., Lund, 1977.

Carlsson, D., and Karn, A., “Att gräva ut en silverdepå ...”, Populär Arkeologi 4 (2014), 24-25.

Carr, G., "Coins, crests and kings: symbols of identity and resistance in the Occupied Channel Islands", Journal of Material Culture 17 (2012), 327-44.

Casey, J., and Reece, R. (eds.), Coins and the Archaeologist, Oxford, 1974.

Casey, J., and Reece, R. (eds.), Coins and the Archaeologist, 2nd ed., London, 1988.

Ciric, G., "A secondary use of Roman coins? Possibilities and limitations of object biography", in H.P. Hahn and H. Weiss (eds.), Mobility, Meaning and the Transformations of Things: Shifting Contexts of Material Culture through Time and Space, Oxford, 2013, 107-19.

Clarke, H., and Schia, E. (eds.), Coins and Archaeology: Proceedings of the First Meeting at Isegran, Norway, 1988, Oxford, 1989.

Codine-Trécourt, F., Les monnaies mérovingiennes modifiées à des fins non monétaires: usages et perceptions des métaux précieux, Paris, 2011.

Corcoran-Tadd, N., “'Is this the gold that you eat?': coins, entanglement, and early colonial orderings in the Andes (AD 1532-ca. 1650)", in L. Der and F. Fernandini (eds.), Archaeology of Entanglement, Abingdon, 2016, 49-76.

Creighton, J., Coins and Power in Late Iron Age Britain, Cambridge, 2000.

Cunliffe, B. (ed.), "Currency”, World Archaeology 6:3 (1975).

Dalton, G. (ed.), Studies in Economic Anthropology, Washington D.C., 1971.

Dubuis, O.F., and Frey-Kupper, S. (eds.), Trouvailles monétaires d'églises: actes du premier colloque international du Groupe suisse pour l'étude des trouvailles monétaires (Lucerne, 19 novembre 1993), Lausanne, 1995.

Dubuis, O.F., Frey-Kupper, S., and Perret, G. (eds.), Trouvailles monétaires de tombes: actes du deuxième colloque international du Groupe suisse pour l'étude des trouvailles monétaires (Neuchâtel, 3-4 mars 1995), Lausanne, 1999.

Eckardt, H., and Williams, H., "Objects without a past? The use of Roman objects in early Anglo-Saxon graves”, in H. Williams (ed.), Archaeologies of Remembrance: Death and Memory in Past Societies, New York, 2003, 141-70.

Eskildsen, K.R., "The language of objects: Christian Jürgensen Thomsen's science of the past", Isis 103 (2012), 24-53. 
Evans, J., "Errors respecting the coinage of the ancient Celtic kings of Britain", Numismatic Chronicle 18 (1856), 161-65.

Evans, J., "On the date of British coins", Numismatic Chronicle 12 (1850), 127-37.

Evans, J., "On the occurrence of flint implements in undisturbed beds of gravel, sand and clay", Archaeologia 38 (186o), 280-307.

Farquahar, H., "Royal charities. Part I: Angels as healing-pieces for the king's evil", British Numismatic Journal 12:2 (1916), 39-135.

Fennell, C.F., "Conjuring boundaries: inferring past identities from religious artifacts", International Journal of Historical Archaeology 4 (2000), 281-313.

Graeber, D., Toward an Anthropological Theory of Value: The False Coin of Our Own Dreams, New York, 2001.

Grierson, P., The Coins of Medieval Europe, London, 1991.

Grierson, P., "Commerce in the Dark Ages", in Dalton, Studies in Economic Anthropology, $74-83$.

Grierson, P. “The interpretation of coin finds (I). The president's address, session 19645, delivered 16 June 1965", Numismatic Chronicle, 7 th ser., 5 (1965), i-xvi.

Grierson, P., "The interpretation of coin finds (II). The president's address, session 1965-1966, delivered 15 June 1966", Numismatic Chronicle, 7 th ser., 6 (1966), i-xxi.

Gullbekk, S.H., "Natural and money economy in medieval Norway", Scandinavian Journal of History 30 (2005), 3-19.

Gullbekk, S.H., Pengevesendets framvekst og fall i Norge $i$ middelalderen, Copenhagen, 2009 .

Gullbekk, S.H, Kilger, C., Roland, H., and Kristensen, S. (eds.), The Use of Money in Religious and Devotional Contexts: Coin Finds in Churches in Scandinavia, Iceland and the Alpine Region, Abingdon, forthcoming, 2018.

Hall, M.A., "Money isn't everything: the cultural life of coins in the medieval burgh of Perth, Scotland", Journal of Social Archaeology 12 (2012), 72-91.

Hall, M.A., "'Pennies from heaven': money in ritual in medieval Europe”, in Haselgrove and Krmnicek, The Archaeology of Money, 137-59.

Haselgrove, C., "The development of Iron Age coinage in Belgic Gaul", Numismatic Chronicle 159 (1999), 111-68.

Haselgrove, C., and Krmnicek, S., "The archaeology of money", Annual Review of Anthropology 41 (2012), 235-50.

Haselgrove, C., and Krmnicek, S. (eds.), The Archaeology of Money. Proceedings of the Workshop "Archaeology of Money", University of Tübingen, October 2013, Leicester, 2016.

Haselgrove, C., and Wigg-Wolf, D. (eds.), Iron Age Coinage and Ritual Practices, Mainz, 2005.

Heijne, C. von Särpräglat: vikingatida och tidigmedeltida myntfynd från Danmark, Skåne, Blekinge och Halland (ca 80o-1130), Stockholm, 2004. 
Herrmann, J., Ralswiek auf Rügen: die slawisch-wikingischen Siedlungen und deren Hinterland. T. 4: Die Silberschatz vor 850: Naturwissenschaftlische Untersuchungen: Versuch einer Bilanz, Schwerin, 2006.

Herva, V.P., Nurmi, R., and Symonds, J., "Engaging with money in a northern periphery of early modern Europe", Journal of Social Archaeology 12 (2012), 287-309.

Hodder, I., "Distributions of Iron Age material", in J. Collis (ed.), The Iron Age in Britain: A Review, Sheffield, 1977, 8-16.

Hoskins, J., Biographical Objects: How Things Tell the Stories of Peoples' Lives, New York, 1998.

Jersey, P. de, "Evans and ancient British coins", in MacGregor, Sir John Evans, 152-72.

Kaenel, H.-M. von, Brem, H., Elmer, J.T., Gorecki, J., Hedinger, B., King, C.E., Klee, M., Leuthard, M., Northover, J.P., Rychener, J., and Zürcher, A., Der Münzhort aus dem Gutshof in Neftenbach. Antoniniane und Denare von Septimius Severus bis Postumus, Zürich, 1993 .

Kaenel, H.-M. von, and Kemmers, F. (eds.), Coins in Context 1: New Perspectives for the Interpretation of Coin Finds, Mainz, 2009.

Kelleher, R., "Pilgrims, pennies and the ploughzone: folded coins in medieval Britain", in Burström and Ingvardson, Divina Moneta, 68-86.

Kemmers, F., and Myrberg, N., "Re-thinking numismatics: the archaeology of coins", Archaeological Dialogues 18 (2011), 87-108.

Kilger, C., "Kombinationer av föremål: de vikingatida mittspännedepåerna", in K. Chilidis (ed.), Facets of Archaeology: Essays in Honour of Lotte Hedeager on Her 6oth Birthday, Oslo, 2008, 323-38.

Kilger, C., "Moving money, ritual money: studying monetary and ritual space in Bunge church on medieval Gotland", in Gullbekk, Kilger, Roland, and Kristensen, The Use of Money in Religious and Devotional Contexts, 2018.

King, C., "Evans and the Roman coinage", in MacGregor, Sir John Evans, 173-88.

King, J.M., "Grave-goods as gifts in early Saxon burials (ca. AD 450-6oo)", Journal of Social Archaeology 4 (2004), 214-38.

Klackenberg, H., Moneta Nostra. Monetarisering i medeltidens Sverige, Stockholm, 1992. Klindt-Jensen, O., A History of Scandinavian Archaeology, London, 1975.

Kool, R., "Lead Token Money in the Kingdom of Jerusalem", Numismatic Chronicle 173 (2013), 293-339, and plates 49-54.

Krmnicek, S., "Coins in odd context", in F. Kemmers, T. Maurer, and B. Rabe, Lege Artis: Festschrift für Hans-Markus von Kaenel, Bonn, 2014, 173-83.

Krmnicek, S., "Das Konzept der Objektbiographie in der antiken Numismatik", in Kaenel and Kemmers, Coins in Context 1, 47-59.

Laing, L.R., Coins and Archaeology, London, 1969.

Le Goff, J., Money and the Middle Ages: An Essay in Historical Anthropology, Cambridge, 2012. 
Little, B.J., Historical Archaeology: Why the Past Matters, Walnut Creek, Cal., 2007.

Luley, B.P., "Coinage at Lattara: using archaeological context to understand ancient coins", Archaeological Dialogues 15 (2008), 174-95.

MacGregor, A., "Sir John Evans, model Victorian, polymath and collector", in MacGregor, Sir John Evans, 2008, 1-38.

MacGregor, A. (ed.), Sir John Evans (1823-1908): Antiquity, Commerce and Natural Science in the Age of Darwin, Oxford, 2008.

Mauss, M., "Essai sur le don: forme et raison de l'échange dans les sociétés primitives", L’Année Sociologique, 2nd ser., 1 (1925 for 1923-1924), 30-186.

Moesgaard, J.C., "Bønders møntbrug i middelalderen. Hvad detektorfundne mønter fortæller", Meta: medeltidsarkeologisk tidskrift 3 (2005), 53-67.

Moesgaard, J.C., "Reconstructing the context of metal detector finds from top soil. A case study of the redundant churches of Oldrup and Uld, Jutland, Denmark" (manuscript).

Montelius, O., "Typologien eller utvecklingsläran tillämpad på det menskliga arbetet", Svenska fornminnesföreningens tidskrift 10 (1899), 237-68.

Myrberg, N., "The colour of money: crusaders and coins in the thirteenth-century Baltic Sea", in F. Fahlander and A. Kjellström (eds.), Making Sense of Things: Archaeologies of Sensory Perception, Stockholm, 2010, 83-102.

Myrberg, N., "The hoarded dead: late iron age silver hoards as graves", in I.-M. Back Danielsson, I. Gustin, A. Larsson, N. Myrberg, and S. Thedéen (eds.), On the Threshold: Burial Archaeology in the Twenty-First Century, Stockholm, 2009, 131-45.

Myrberg, N. (ed.), "Numismatik mellan historia och arkeologi", Meta: Medeltidsarkeologisk tidskrift 27:3 (2005), 3-10.

Myrberg, N., "The social identity of coin hoards-and other examples of theory and practice in the space between numismatics and archaeology", in Kaenel and Kemmers, Coins in Context 1, 157-71.

Naismith, R., Medieval European Coinage, with a Catalogue of the Coins in the Fitzwilliam Museum, Cambridge, Vol. 8: Britain and Ireland c.400-1066, Cambridge, 2017.

Neale, W.C., "Monetization, commercialization, market orientation, and market dependence", in Dalton, Studies in Economic Anthropology, 1971, 25-29.

Orser, C.E., "Introduction", in C.E. Orser (ed.), Encyclopedia of Historical Archaeology, London, 2002, xiii-xvi.

Papadopoulos, J.K., and Urton, G., "Introduction", in J.K. Papadopoulos and G. Urton (eds.), The Construction of Value in the Ancient World, Los Angeles, 2012, 1-47.

Parry, J., and Bloch, M. (eds.), Money and the Morality of Exchange, Cambridge, 1989.

Perassi, C., "Coins and baptism in late antiquity: written sources and numismatic evidence reconsidered", in Burström and Ingvardson, Divina Moneta, 2017, 49-67.

Rispling, G., "Spännande mynt i Spillingsskatten”, Gotländskt Arkiv 76 (2004), 123-32. 
Risvaag, J.A., "Echoes of the mother church in a remote valley: Høre Stave Church, Oppland, Norway", in Gullbekk, Kilger, Roland, and Kristensen, The Use of Money in Religious and Devotional Contexts, 2018.

Russell, A.E., "Material culture and African-American spirituality at the Hermitage", Historical Archaeology 31 (1997), 63-8o.

Schlanger, N., "Coins to flint:John Evans and the numismatic moment in the history of archaeology”, European Journal of Archaeology 14 (2011), 465-79.

Schlanger, N., "Series in progress: antiquities of nature, numismatics and stone implements in the emergence of prehistoric archaeology (1776-1891)", History of Science 48 (2010), 344-69.

Schnapp, A., The Discovery of the Past: The Origins of Archaeology, London, 1996.

Spufford, P., Money and Its Use in Medieval Europe, Cambridge, 1988.

Strathern, M., The Gender of the Gift:Problems with Women and Problems with Society in Melanesia, Berkeley, 1988.

Straube, B.A., "Numismatic portals to the past: archaeological evidence of an undocumented seventeenth-century fiscal scheme for Jamestown, Virginia", in Haselgrove and Krmnicek, The Archaeology of Money, 2016, 183-208.

Syon, D., "A crusader token mould from Akko", Israel NumismaticJournal13(1999), 163-66.

Thomsen, C.J., Ledetraad til Nordisk Oldkyndighet, Copenhagen, 1836.

Thordeman, B., Korsbetningen och Solberga kloster utanför Visby, Stockholm, 1930.

Thordeman, B., "Myntfynden i Korsbetningens massgravar", Fornvännen 27 (1932), 23$39,65-87$.

Thunmark-Nylén, L., Die Wikingerzeit Gotlands, Vol. 3, Part 2, Stockholm, 1998.

Travaini, L., "Saints and sinners: coins in medieval Italian graves", Numismatic Chronicle 164 (2004), 159-81.

Travaini, L., "Saints, sinners and ... a cow: offerings, alms and tokens of memory", in G.E.M. Gasper and S.H. Gullbekk (eds.), Money and the Church in Medieval Europe, 1000-1200, Farnham, 2015, 209-21.

Trigger, B.G., A History of Archaeological Thought, Cambridge, 2006.

Weiner, A., Inalienable Possessions: The Paradox of Keeping-While-Giving, Berkeley, 1992. 